SpringerBriefs in Law 
More information about this series at http://www.springer.com/series/10164 
Elena D'Agostino

\section{Contracts of Adhesion Between Law and Economics}

Rethinking the Unconscionability Doctrine

Springer 


\author{
Elena D'Agostino \\ Department of Economics, Business, \\ Environmental and Quantitative Methods \\ University of Messina \\ Messina \\ Italy
}

ISSN 2192-855X

ISBN 978-3-319-13113-9

DOI 10.1007/978-3-319-13114-6
ISSN 2192-8568 (electronic)

ISBN 978-3-319-13114-6 (eBook)

Library of Congress Control Number: 2014954618

Springer Cham Heidelberg New York Dordrecht London

(C) The Author(s) 2015

This work is subject to copyright. All rights are reserved by the Publisher, whether the whole or part of the material is concerned, specifically the rights of translation, reprinting, reuse of illustrations, recitation, broadcasting, reproduction on microfilms or in any other physical way, and transmission or information storage and retrieval, electronic adaptation, computer software, or by similar or dissimilar methodology now known or hereafter developed. Exempted from this legal reservation are brief excerpts in connection with reviews or scholarly analysis or material supplied specifically for the purpose of being entered and executed on a computer system, for exclusive use by the purchaser of the work. Duplication of this publication or parts thereof is permitted only under the provisions of the Copyright Law of the Publisher's location, in its current version, and permission for use must always be obtained from Springer. Permissions for use may be obtained through RightsLink at the Copyright Clearance Center. Violations are liable to prosecution under the respective Copyright Law.

The use of general descriptive names, registered names, trademarks, service marks, etc. in this publication does not imply, even in the absence of a specific statement, that such names are exempt from the relevant protective laws and regulations and therefore free for general use.

While the advice and information in this book are believed to be true and accurate at the date of publication, neither the authors nor the editors nor the publisher can accept any legal responsibility for any errors or omissions that may be made. The publisher makes no warranty, express or implied, with respect to the material contained herein.

Printed on acid-free paper

Springer is part of Springer Science+Business Media (www.springer.com) 


\section{Contents}

1 The Unconscionability Doctrine in a Law and Economics

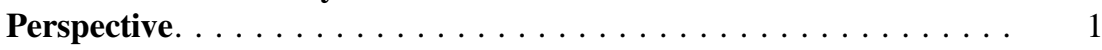

1.1 What Is a Contract of Adhesion? . . . . . . . . . . . . 1

1.2 Freedom of Contract (of Adhesion?) and Consumer

Protection ..................... 3

1.3 The Traditional Legal Reasons to Protect Consumers . . . . . . . . 7

1.3.1 Market Power ................... 8

1.3.2 Lack of Sophistication ............... 9

1.3.3 Contract Complexity. . . . . . . . . . . . . 11

1.4 When Price Is Not the Only Cost for Consumers . . . . . . . . . . . . . . . . 12

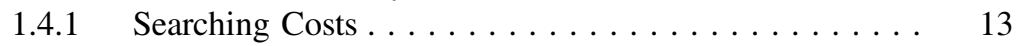

1.4 .2 Reading Costs . . . . . . . . . . . . . . . . . . . . 14

1.5 When Production Costs Are Not the Only Cost for Sellers . . . . 16

1.5.1 Writing (or Printing) Costs . . . . . . . . . . . . . 16

1.5.2 Disclosing (or Speaking) Costs . . . . . . . . . . . 16

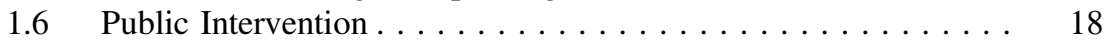

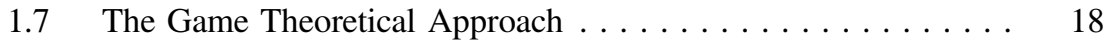

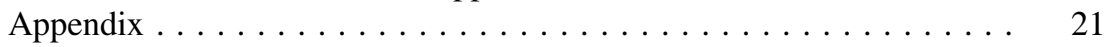

2 Market Structure . . . . . . . . . . . . . . . . . . 23

2.1 The "Market Structure Hypothesis" . . . . . . . . . . . . . . 23

2.2 The Critics to the "Market Structure" Hypothesis . . . . . . . . . . 24

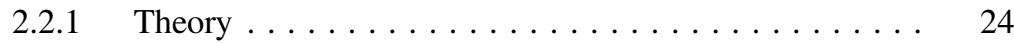

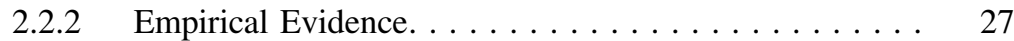

2.3 Doesn't Market Structure Matter at All? . . . . . . . . . . . 27

Appendix ........................... 29 


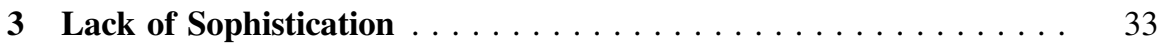

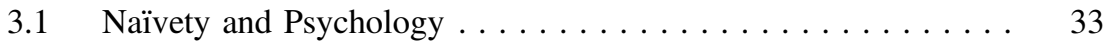

3.2 Naïvety and Law . . . . . . . . . . . . . . . . 35

3.3 Naïvety and Economics. . . . . . . . . . . . . . . 36

3.4 Market Structure and Naïve Consumers. . . . . . . . . . . . . . . . . . . . . . . . . . . . . . . . . . . . . . 48

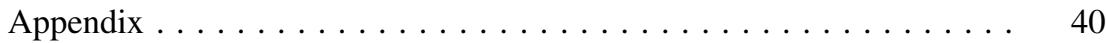

4 Voluntary Disclosure of Clauses . . . . . . . . . . . . . . . . 43

4.1 How to Disclose Contract Clauses . . . . . . . . . . . . . . 43

4.2 Voluntary Disclosure When Some Consumers Are Naïve . . . . . 45

4.3 Voluntary Disclosure When Consumers Are All

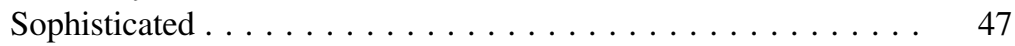

4.4 Is Disclosure at Least Effective $. \ldots \ldots \ldots \ldots . \ldots \ldots$. . . . . . . . . . . 49

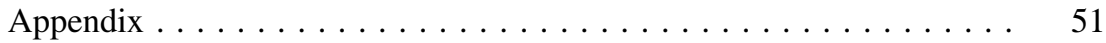

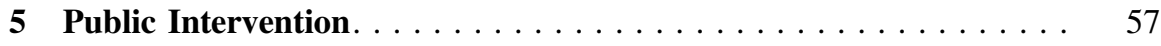

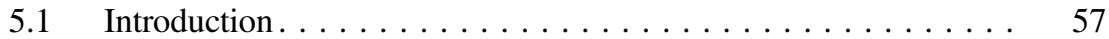

5.2 The US System . . . . . . . . . . . . . . . 57

5.2 .1 From Unconscionability............... 58

$5.2 .2 \ldots$ to the Theory of Mandated Disclosure . . . . . . . . 60

5.3 The "Informed Minority" Hypothesis .............. 62

5.3.1 Critics to the "Informed Minority" Hypothesis:

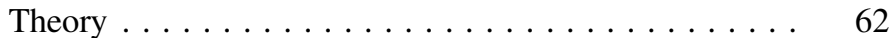

5.3.2 Critics to the "Informed Minority" Hypothesis: Empirical Evidence. . . . . . . . . . . . . . . 63

5.4 Who Gains from Mandatory Disclosure?............. 64

5.5 The EU System . . . . . . . . . . . . . . . . . . 66

5.5.1 From the German Statute................ 66

$5.5 .2 \ldots$ to the $93 / 13 /$ EEC Directive . . . . . . . . . . 68

5.6 Who Gains from Mandatory Friendly Clauses? . . . . . . . . . . 69

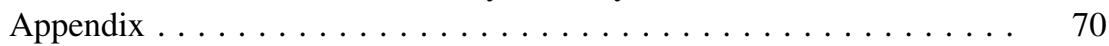

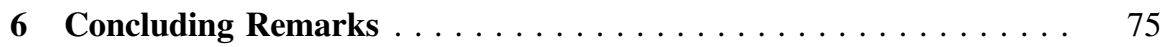

References. . . . . . . . . . . . . . . . . . . . . 77 